\title{
Zjawiska aerodynamiczne wywołane przejazdem pociągu. Część 2: Oddziaływanie ciśnienia na mijające się pociągi
}

\author{
Andrzej ZBIEĆ ${ }^{1}$
}

\begin{abstract}
Streszczenie
W cyklu artykułów opisujących zjawiska aerodynamiczne wywołane przejazdem pociągu scharakteryzowano oddziaływania pociągu jadącego $z$ dużą prędkością na sam jadący pociąg, na inne pociągi, na obiekty znajdujące się przy torze oraz na ludzi. Oddziaływanie to może być dwojakiego rodzaju: przez wytwarzane ciśnienie i przez podmuch. Oprócz analizy literatury, uwzględniono badania przeprowadzone przez autora. W drugiej części cyklu opisano oddziaływanie zmian ciśnienia na powierzchnie czołowe i boczne mijających się pociągów oraz przedstawiono wnioski dotyczące szyb bocznych i czołowych w szybkich pojazdach kolejowych i w pojazdach kolejowych starszego typu o mniejszych prędkościach dopuszczalnych, a także możliwości eksploatacji różnego taboru na tych samych liniach.
\end{abstract}

Słowa kluczowe: tabor kolejowy, koleje dużych prędkości, zjawiska aerodynamiczne

\section{Wstęp}

W części pierwszej cyklu opisano ogólną klasyfikację zjawisk aerodynamicznych, które ze względu na rodzaj oddziaływania podzielono na zmiany ciśnienia oraz podmuch. Zaprezentowano przebieg zmian ciśnienia w otwartej przestrzeni wywołanych przejazdem pociągu oraz oddziaływanie ciśnienia na różne obiekty znajdujące się przy torze. Wskazano podstawowe dokumenty normatywne dotyczące zagadnień aerodynamicznych. Przedstawiono wnioski dotyczące budowy szybkiego pojazdu kolejowego oraz wytrzymałości i usytuowania konstrukcji przy liniach dużych prędkości. Część druga cyklu jest kontynuacją zagadnień dotyczących zmian ciśnienia, lecz tym razem wynikających $\mathrm{z}$ wzajemnego oddziaływania poruszających się pociągów na ich powierzchnie czołowe i boczne.

\section{Oddziaływanie ciśnienia na powierzchnie boczne pociągów}

Podobnie, jak przejeżdżający pociąg oddziałuje na obiekty położone w pobliżu toru, tak samo oddziałuje na inny pociąg stojący lub jadący po sąsiednim torze. Ponieważ boczna siła aerodynamiczna (działająca prostopadle do powierzchni pociągu) rośnie proporcjonalnie do kwadratu prędkości, należy przeanalizować, czy osiągane wartości sił (ciśnień) nie powodują zagrożenia dla konstrukcji pudeł mijanych pojazdów.

Jak wykazano w pracy [6], pociąg poruszający się z dużymi prędkościami oddziałuje na pociąg poruszający się wolniej oraz na inne obiekty, a nie odwrotnie. Podobne wnioski przytoczono $\mathrm{w}$ raporcie [1] oraz $\mathrm{w}$ pracach innych autorów $[2,3,11]$ :

1. „Amplituda fali ciśnienia indukowanej przez przejeżdżający pociąg na pociąg obserwacyjny podczas przejazdu zależy tylko od prędkości przejeżdżającego pociągu, jego kształtu nosa i odległości między dwoma pociągami, ale nie od prędkości pociągu obserwacyjnego";

2. „Podczas gdy amplituda impulsu ciśnienia generowanego przez przejeżdżający pociąg jest teoretycznie niezależna od ruchu pociągu obserwacyjnego, pomiary przeprowadzone przez Francuzów i Niemców wykazały $30 \div 40 \%$ wzrost współczynników różnicy ciśnień, gdy zarówno pociąg przejeżdżający, jak i obserwacyjny jechały z tą samą prędkością";

3. „Wykonano pomiary eksperymentalne, aby zmierzyć ciśnienie aerodynamiczne generowane między dwoma przejeżdżającymi pociągami. Kiedy jadący pociąg mija pociąg stacjonarny, ciśnienie aerodynamiczne wywierane na pociąg stacjonarny jest silniejsze niż ciśnienie w pociągu w ruchu”.

\footnotetext{
${ }^{1}$ Mgr inż.; Instytut Kolejnictwa, Laboratorium Badań Taboru; e-mail: azbiec@ikolej.pl.
} 
Na rysunku 1 zaprezentowano wyniki symulacji wykonanych na modelu dwuwymiarowym dla czterech wariantów ruchu pociągów:

- pociąg oprzyrządowany w czujniki ciśnienia (testowy) porusza się w otwartej przestrzeni,

- oba pociągi jadą z tymi samymi prędkościami w przeciwnych kierunkach,

- pociąg oprzyrządowany w czujniki ciśnienia (testowy) mija pociąg stojący,

- pociąg jadący mija stojący pociąg testowy, oprzyrządowany w czujniki ciśnienia.

Bezwymiarowy współczynnik ciśnienia $\Delta \mathrm{Cp}$ (Pressure Coefficient) w punkcie P-1 nadwozia przedstawiono jako funkcję odległości pomiędzy pociągami, odniesioną do szerokości pociągów - bezwymiarowa wielkość $\mathrm{X}$.

Z przedstawionych obliczeń jednoznacznie wynika, że największy pik ciśnienia występuje w sytuacji, w której pociąg jadący mija inny pociąg stojący i wówczas na ścianie bocznej pociągu stojącego indukowane są duże zmiany ciśnienia. Druga co do wielkości zmiana ciśnienia powstaje w sytuacji, kiedy oba pociągi mijają się jadąc $\mathrm{z}$ tymi samymi prędkościami. W związku z tym nie ma niebezpieczeństwa związanego $\mathrm{z}$ oddziaływaniem ciśnienia wytworzonego przez pociąg poruszający się wolniej, na pociąg poruszający się z dużymi prędkościami. Gdy wyniki pomiarów lub symulacji są niedostępne, do obliczenia oddziaływania mijających się pociągów można wykorzystać te same wzory, co w przypadku oddziaływania ciśnienia na konstrukcje pionowe (rozdział 2.2. w części 1).

Do obliczenia wartości ciśnienia $p_{b}$ na ścianie bocznej mijanego pociągu, przyjęto najbardziej niekorzystne założenie, że pociąg ten znajduje się możliwie najbliżej pociągu szybkiego, czyli - jak pokazano na rysunku 2, jego ściana boczna styka się ze skrajnią kinematyczną (wymiar $1645 \mathrm{~mm}$ od osi toru według normy PN-EN 15273-2 [9]). W rzeczywistości odległość pomiędzy pociągami będzie nieco większa, a ciśnienia nieco mniejsze niż obliczone poniżej, ponieważ przeciętne szerokości polskich wagonów osobowych wynoszą od $2,68 \mathrm{~m}$ do $2,88 \mathrm{~m}$. Zgodnie z TSI INF [10] stosuje się następujące minimalne szerokości międzytorza (odległości pomiędzy osiami sąsiednich torów, po których poruszają się oba pociągi):

- $3,8 \mathrm{~m}$ dla prędkości $160 \mathrm{~km} / \mathrm{h}<V \leq 200 \mathrm{~km} / \mathrm{h}$;

- 4,0 m dla prędkości $200 \mathrm{~km} / \mathrm{h}<V \leq 250 \mathrm{~km} / \mathrm{h}$;

- 4,2 m dla prędkości $250 \mathrm{~km} / \mathrm{h}<V \leq 300 \mathrm{~km} / \mathrm{h}$;

- 4,5 m dla prędkości $V>300 \mathrm{~km} / \mathrm{h}$.

W tablicy 1 oraz na rysunku 3 pokazano ciśnienia na ścianie bocznej mijanego pociągu konwencjonalnego, w zależności od prędkości pociągu szybkiego oraz szerokości międzytorza.

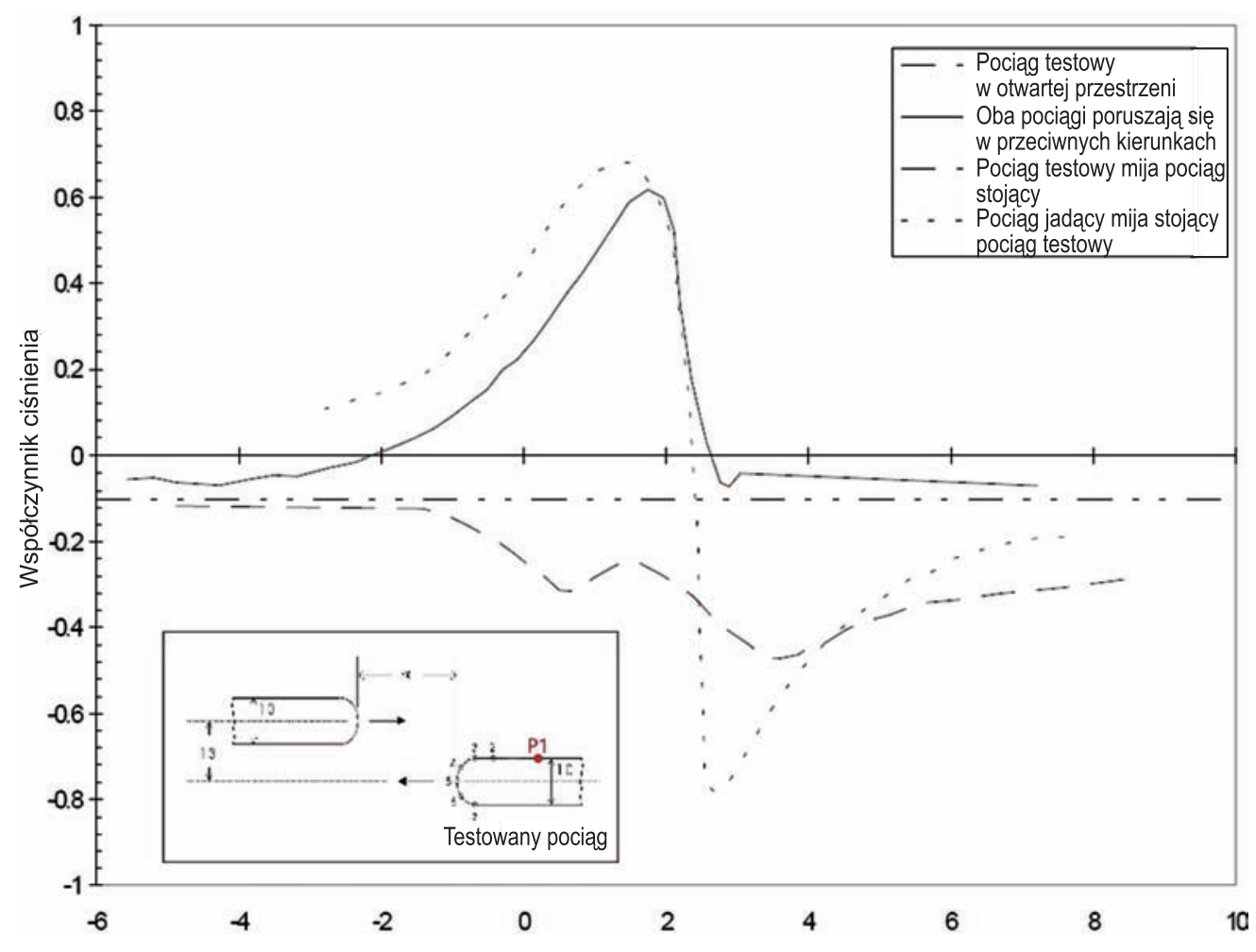

Rys. 1. Ciśnienie na ścianie bocznej testowego pociągu [1, 11] 
Rys. 2. Ciśnienie na ścianie bocznej mijanego pociągu [opracowanie własne]

\section{Ciśnienia na ścianie bocznej mijanego pociągu}

\begin{tabular}{|c|c|c|c|c|}
\hline \multirow{2}{*}{\begin{tabular}{c}
\multirow{2}{*}{$\boldsymbol{V}_{\mathbf{1}}[\mathbf{k m} / \mathbf{k}$ / $]$} \\
\end{tabular}} & \multicolumn{4}{|c|}{ Ciśnienie $\boldsymbol{p}_{\boldsymbol{b}}[\mathrm{Pa}]$} \\
\cline { 2 - 5 } & $\mathbf{3 , 8}[\mathbf{m}]$ & $\mathbf{4 , 0}[\mathbf{m}]$ & $\mathbf{4 , 2}[\mathbf{m}]$ & $\mathbf{4 , 5}[\mathbf{m}]$ \\
\hline $\mathbf{1 6 0}$ & 328,3 & 282,0 & 245,2 & 202,8 \\
\hline $\mathbf{1 8 0}$ & 415,5 & 356,8 & 310,3 & 256,6 \\
\hline $\mathbf{2 0 0}$ & 512,9 & 440,6 & 383,1 & 316,8 \\
\hline $\mathbf{2 2 0}$ & - & 533,1 & 463,5 & 383,3 \\
\hline $\mathbf{2 4 0}$ & - & 634,4 & 551,6 & 456,2 \\
\hline $\mathbf{2 5 0}$ & - & $\mathbf{6 8 8 , 4}$ & $\mathbf{5 9 8 , 6}$ & $\mathbf{4 9 5 , 0}$ \\
\hline $\mathbf{2 6 0}$ & - & - & 647,4 & 535,4 \\
\hline $\mathbf{2 8 0}$ & - & - & 750,8 & 620,9 \\
\hline $\mathbf{3 0 0}$ & - & - & 861,9 & 712,8 \\
\hline $\mathbf{3 2 0}$ & - & - & - & 811,0 \\
\hline $\mathbf{3 4 0}$ & - & - & - & 915,6 \\
\hline $\mathbf{3 5 0}$ & - & - & - & 970,2 \\
\hline
\end{tabular}

[Opracowanie własne].

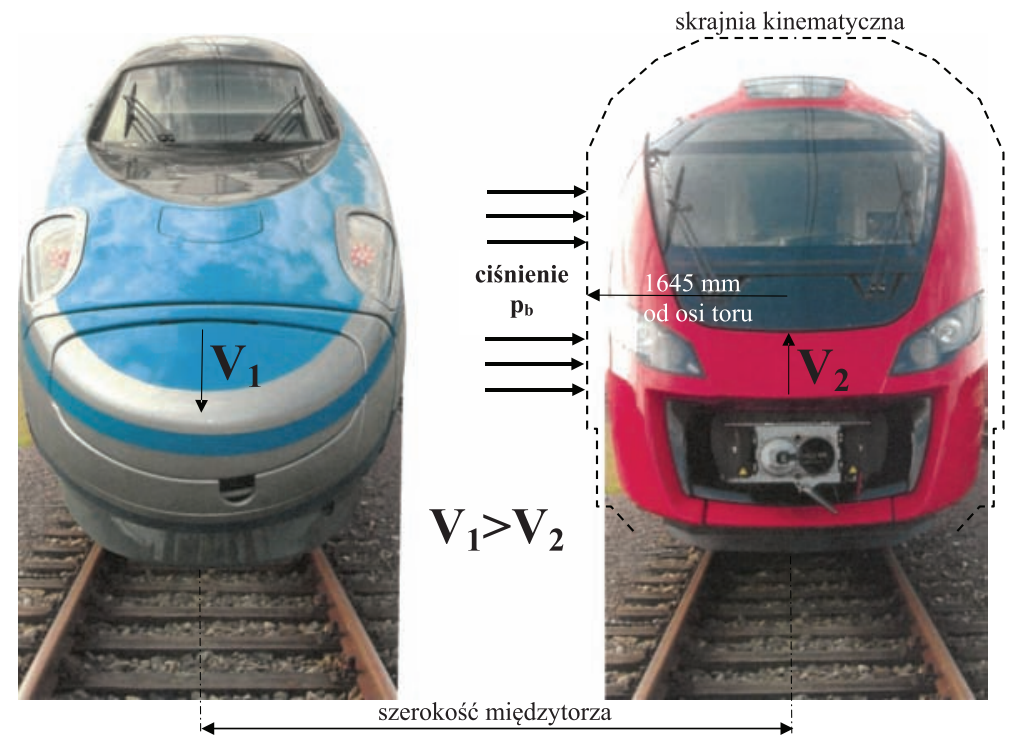

Zgodnie z tablicą 1, maksymalna wartość ciśnienia działającego na jadący lub stojący na sąsiednim torze pociąg wynosi poniżej $1000 \mathrm{~Pa}$. Taka wartość ciśnienia nie jest niebezpieczna dla poszycia wagonów osobowych i towarowych oraz innych elementów stałych. Jedynym elementem wagonu osobowego, który mógłby zostać uszkodzony przez działanie szybkozmiennej fali ciśnienia jest okno. Jednakże, zgodnie $\mathrm{z}$ kartą UIC 566 [4] p. 4.2.2.2, okna są poddawane następującym wytrzymałościowym badaniom zmęczeniowym:

- $\pm 2500 \mathrm{~Pa}$ - ciśnienie obciążające;

- $10^{6}$ - liczba cykli obciążeń;

- $3 \mathrm{~Hz}$ - częstotliwość obciążenia.

Jak wynika $\mathrm{z}$ przedstawionych parametrów badania okien, nawet największe obciążenie ciśnieniem od przejeżdżającego po sąsiednim torze pociągu z prędkością $350 \mathrm{~km} / \mathrm{h}$, przy międzytorzu $4,5 \mathrm{~m}$, jest ponad 2,5 razy niższe od ciśnienia podczas próby
Rys. 3. Ciśnienia na ścianie bocznej mijanego pociągu [opracowanie własne]

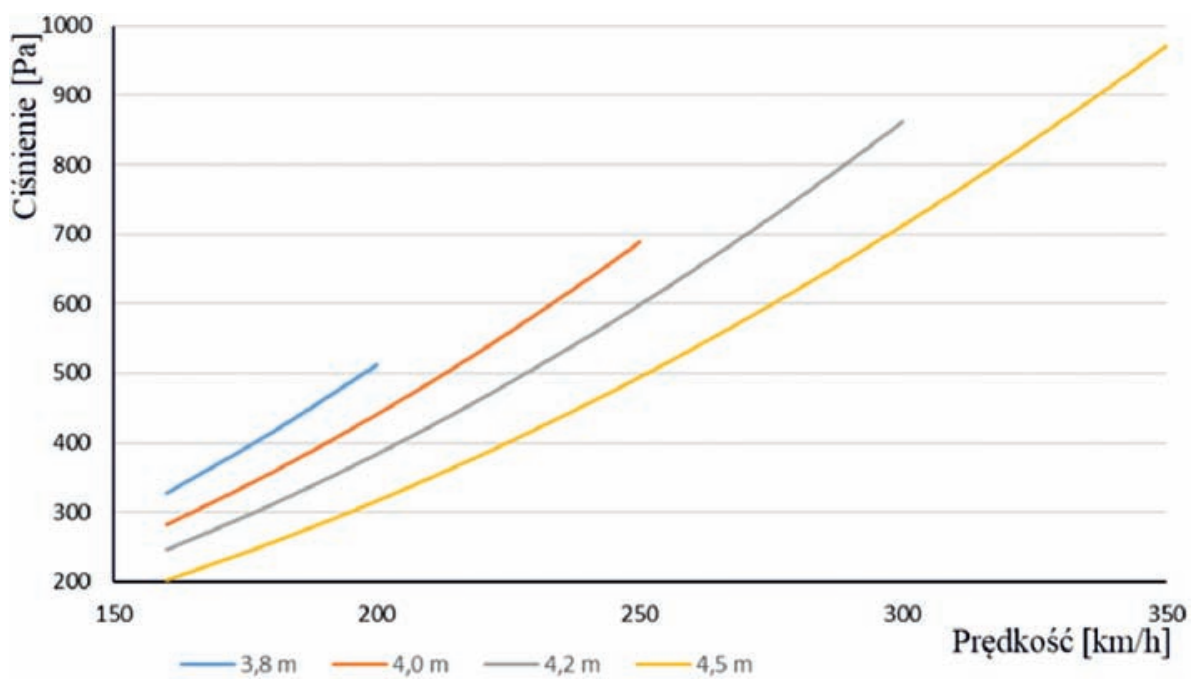


zmęczeniowej. Przy międzytorzach o mniejszych szerokościach, dopuszczalne prędkości jazdy są mniejsze i odpowiadające im ciśnienia maksymalne są również mniejsze (odpowiednio 2,9 razy, 3,6 razy i 4,9 razy). Można zatem stwierdzić, że wszystkie wagony pasażerskie i zespoły trakcyjne, których okna przebadano na zgodność z kartą UIC 566 [4], mogą bez żadnych ograniczeń kursować na tych samych trasach co pociągi szybkie. Nie ma konieczności wymiany okien $\mathrm{w}$ tych wagonach, zwiększania szerokości międzytorza albo podejmowania innych środków zaradczych. Jedynym niebezpieczeństwem jest „wyssanie” całej szyby w przypadku zbyt słabego jej zamocowania w poszyciu pojazdu. Siła działająca na okno jest wprost proporcjonalna do jego powierzchni. Zatem przy tym samym ciśnieniu: im większa powierzchnia okna, tym większe siły działające na okno i tym mocniejsze musi być jego zamocowanie.

\section{Oddziaływanie ciśnienia na powierzchnie czołowe pociągów}

Zagadnienie oddziaływania ciśnienia na powierzchnie czołowe pociągów zostało zawężone do oddziaływania ciśnienia na szyby czołowe. Podobnie jak dla oddziaływań na powierzchnie boczne przyjęto, że poszycie pojazdów jest odpowiednio wytrzymałe i jedynym elementem, który mógłby zostać uszkodzony przez działanie szybkozmiennej fali ciśnienia jest szyba czołowa pojazdów trakcyjnych. Oddziaływanie ciśnienia na szyby czołowe ma inny charakter, niż oddziaływanie ciśnienia na szyby boczne. Ponadto, odwrotnie niż przy oddziaływaniu na powierzchnie boczne pociągów, to szyba czołowa pociągu jadącego szybciej będzie narażona na oddziaływanie większego ciśnienia, a wpływ ciśnienia pochodzącego od pociągu jadącego po sąsiednim torze będzie mniejszy. Jednakże należy sprawdzić wielkość tego ciśnienia, działającego na szyby czołowe lokomotyw ciągnących pociągi konwencjonalne i elektryczne zespoły trakcyjne starszej konstrukcji oraz na pociągi przeznaczone do kursowania $\mathrm{z}$ dużymi prędkościami, pomimo że powinny być już wyposażone w odpowiednio wytrzymałe okna. Norma PN-EN 14067-4 [7] nie podaje żadnych wzorów na obliczenie ciśnienia na czole pojazdu. Obliczenia przeprowadzono za pomocą wzoru, zaczerpniętego z pracy [6]:

$$
p_{s}=0,5 \cdot \delta_{1} \cdot \rho \cdot V_{p}^{2}+0,5 \cdot \delta \cdot \rho \cdot V_{p m}{ }^{2},
$$

gdzie:

$$
\begin{gathered}
\rho=1,225 \mathrm{~kg} / \mathrm{m}^{3} \text { - gęstość powietrza (przyjęto jak } \\
\text { w rozdziale } 2.2 \mathrm{w} \text { części 1); } \\
V_{p} \text { - prędkość pociągu, dla którego obliczane jest } \\
\text { ciśnienie działające na szyby; } \\
V_{p m} \text { - prędkość pociągu mijanego; }
\end{gathered}
$$

$\delta_{1}$ - współczynnik ciśnienia na powierzchni czołowej lokomotywy, w przypadku szyb czołowych płaskich $\delta_{1}=1$, według [6], s. 64;

$\delta$ - współczynnik wzrostu ciśnienia na czole lokomotywy, dla rozstawu torów $4 \mathrm{~m} \delta=0,6 \div 0,8$, według [6], s. 64.

Do obliczeń przyjęto średnią wartość współczynnika wzrostu ciśnienia na czole lokomotywy (wpływ od pociągu mijanego) $\delta=0,7$. Ponieważ nie podano współczynników dla innych szerokości międzytorza, to dla międzytorza o szerokości $3,8 \mathrm{~m}$ oraz 4,2 m - ze względu na niewielkie różnice szerokości (zaledwie $\pm 20 \mathrm{~cm})$ - przyjęto taką samą wartość tego współczynnika. Jedynie dla międzytorza $4,5 \mathrm{~m}$ (szerszego o $50 \mathrm{~cm})$ przyjęto wartość $\delta(4,5 \mathrm{~m})=0,6$ (im większa szerokość międzytorza, tym wpływ wzrostu ciśnienia od pociągu jadącego po sąsiednim torze będzie mniejszy). Współczynnik ciśnienia na powierzchni czołowej lokomotywy przyjęto jak dla szyb płaskich $\delta_{1}=1$ (przypadek najbardziej niekorzystny). Im kształt szyby i całego czoła pociągu będzie bardziej opływowy, tym współczynnik ten będzie mniejszy, np. dla kuli będzie wynosił $0,2 \div 0,4$.

W tablicy 2 i na rysunku 4 pokazano ciśnienia na szybie czołowej pociągu szybkiego w zależności od prędkości mijających się pociągów, a w tablicy 3 i na rysunku 5 pokazano ciśnienia na szybie czołowej pociągu mijanego w zależności od prędkości obu pociągów. Zgodnie z przytoczonymi w rozdziale 2 minimalnymi wartościami szerokości międzytorza (według TSI INF [10]) przyjęto, że do prędkości $300 \mathrm{~km} / \mathrm{h}$ ruch odbywa się na torach o szerokości międzytorza $3,8 \div 4,2 \mathrm{~m}(\delta=0,7)$, a powyżej tej prędkości na torach o szerokości międzytorza $4,5 \mathrm{~m}$ $(\delta=0,6)$. Stąd zmniejszenie wartości ciśnienia $\mathrm{w}$ tablicy 3 przy wzroście prędkości pociągu szybkiego $\mathrm{z} V_{1}=300 \mathrm{~km} / \mathrm{h}$ do $V_{1}=320 \mathrm{~km} / \mathrm{h}$ oraz nieciągłość krzywych na rysunku 5.

W tablicy 4 pokazano procentowy wzrost ciśnienia na szybie czołowej pociągu szybkiego $\mathrm{w}$ zależności od prędkości pociągu mijanego, odniesionej do ciśnienia przy jego prędkości maksymalnej $V_{1}=350 \mathrm{~km} / \mathrm{h}$ i $V_{2}=0$ (pociąg mijany stoi).

W tablicy 5 pokazano procentowy wzrost ciśnienia na szybie czołowej pociągu mijanego dla różnych prędkości pociągu szybkiego $V_{1}$, odniesiony do ciśnienia przy różnych prędkościach maksymalnych pociągu mijanego $\left(V_{2 \max }=120 / 140 / 160 / 180 / 200 \mathrm{~km} / \mathrm{h}\right)$ i stojącego pociągu szybkiego $\left(V_{1}=0 \mathrm{~km} / \mathrm{h}\right)$.

Tablice 4 i 5 pokazują wyraźnie, że dla pociągu szybkiego o prędkości maksymalnej $350 \mathrm{~km} / \mathrm{h}$ mijanie się z pociągiem wolniejszym, jadącym nawet $200 \mathrm{~km} / \mathrm{h}$ nie powoduje znaczącego wzrostu ciśnienia na jego szybie czołowej - maksymalnie 1,2 razy. Odwrotnie jest $\mathrm{w}$ przypadku pociągu mijanego 
Ciśnienia na szybie czołowej pociągu szybkiego

\begin{tabular}{|c|c|c|c|c|c|c|}
\hline \multirow{3}{*}{$\begin{array}{c}\text { Prędkość } V_{1} \\
\text { (pociągu szybkiego) } \\
{[\mathrm{km} / \mathrm{h}]}\end{array}$} & \multicolumn{6}{|c|}{ Ciśnienie $p_{s}[\mathrm{~Pa}]$} \\
\hline & \multicolumn{6}{|c|}{ Prędkość $V_{2}$ (pociągu mijanego) } \\
\hline & $0 \mathrm{~km} / \mathrm{h}$ & $120 \mathrm{~km} / \mathrm{h}$ & $140 \mathrm{~km} / \mathrm{h}$ & $160 \mathrm{~km} / \mathrm{h}$ & $180 \mathrm{~km} / \mathrm{h}$ & $200 \mathrm{~km} / \mathrm{h}$ \\
\hline $\mathbf{0}$ & 0 & 476 & 648 & 847 & 1072 & 1323 \\
\hline 160 & 1210 & 1686 & 1858 & 2057 & 2282 & 2533 \\
\hline 180 & 1531 & 2008 & 2180 & 2378 & 2603 & 2855 \\
\hline 200 & 1890 & 2367 & 2539 & 2737 & 2962 & 3214 \\
\hline 220 & 2287 & 2764 & 2936 & 3134 & 3359 & 3611 \\
\hline 240 & 2722 & 3199 & 3371 & 3569 & 3794 & 4046 \\
\hline 250 & 2954 & 3430 & 3602 & 3801 & 4026 & 4277 \\
\hline 260 & 3195 & 3671 & 3843 & 4042 & 4267 & 4518 \\
\hline 280 & 3705 & 4182 & 4354 & 4552 & 4777 & 5029 \\
\hline 300 & 4253 & 4730 & 4902 & 5100 & 5325 & 5577 \\
\hline 320 & 4840 & 5248 & 5395 & 5565 & 5758 & 5974 \\
\hline 340 & 5463 & 5872 & 6019 & 6189 & 6382 & 6598 \\
\hline 350 & 5789 & 6198 & 6345 & 6515 & 6708 & 6924 \\
\hline
\end{tabular}

[Opracowanie własne].

Rys. 4. Ciśnienia na szybie czołowej pociągu szybkiego [opracowanie własne]

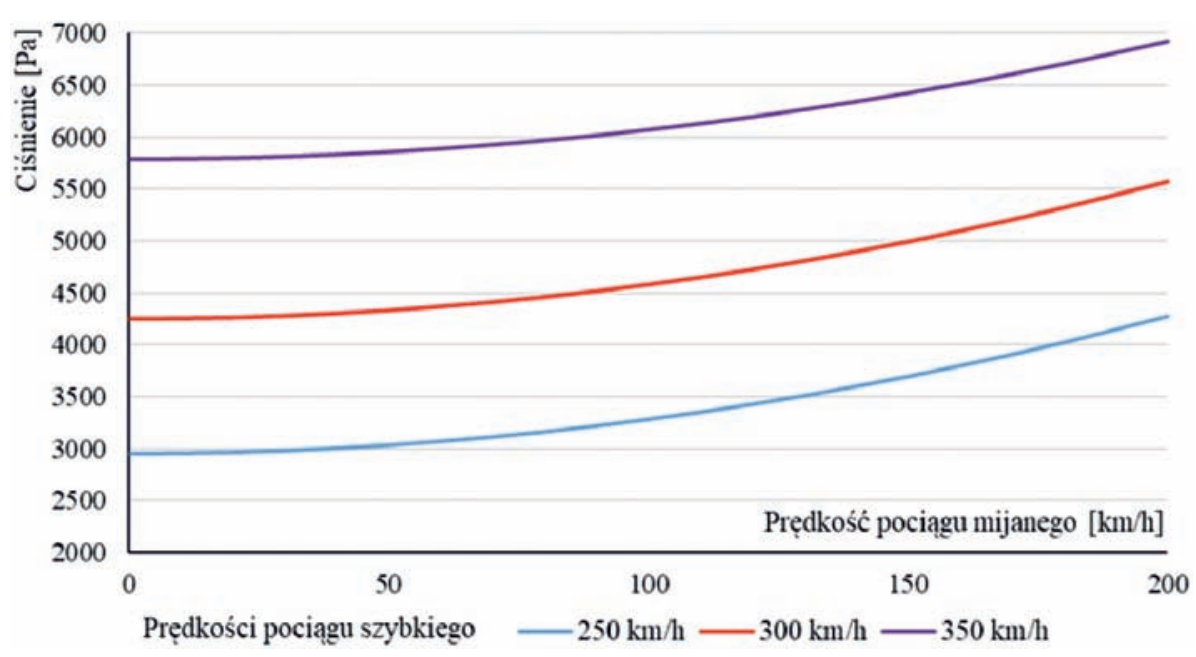

Tablica 3

Ciśnienia na szybie czołowej pociągu mijanego

\begin{tabular}{|c|c|c|c|c|c|c|}
\hline \multirow{3}{*}{$\begin{array}{c}\text { Prędkość } V_{1}(\text { pociągu } \\
\text { szybkiego) }[\mathrm{km} / \mathbf{h}]\end{array}$} & \multicolumn{6}{|c|}{ Ciśnienie $p_{s}[\mathrm{~Pa}]$} \\
\hline & \multicolumn{6}{|c|}{ Prędkość $V_{2}$ (pociągu mijanego) } \\
\hline & $0 \mathrm{~km} / \mathrm{h}$ & $120 \mathrm{~km} / \mathrm{h}$ & $140 \mathrm{~km} / \mathrm{h}$ & $160 \mathrm{~km} / \mathrm{h}$ & $180 \mathrm{~km} / \mathrm{h}$ & $200 \mathrm{~km} / \mathrm{h}$ \\
\hline $\mathbf{0}$ & 0 & 681 & 926 & 1210 & 1531 & 1890 \\
\hline 160 & 847 & 1527 & 1773 & 2057 & 2378 & 2737 \\
\hline 180 & 1072 & 1752 & 1998 & 2282 & 2603 & 2962 \\
\hline 200 & 1323 & 2004 & 2250 & 2533 & 2855 & 3214 \\
\hline 220 & 1601 & 2282 & 2528 & 2811 & 3132 & 3492 \\
\hline 240 & 1906 & 2586 & 2832 & 3115 & 3437 & 3796 \\
\hline 250 & 2068 & 2748 & 2994 & 3278 & 3599 & 3958 \\
\hline 260 & 2236 & 2917 & 3163 & 3446 & 3768 & 4127 \\
\hline 280 & 2594 & 3274 & 3520 & 3804 & 4125 & 4484 \\
\hline 300 & 2977 & 3658 & 3904 & 4187 & 4509 & 4868 \\
\hline 320 & 2904 & 3584 & 3830 & 4114 & 4435 & 4794 \\
\hline 340 & 3278 & 3959 & 4204 & 4488 & 4809 & 5168 \\
\hline 350 & 3474 & 4154 & 4400 & 4684 & 5005 & 5364 \\
\hline
\end{tabular}

[Opracowanie własne]. 


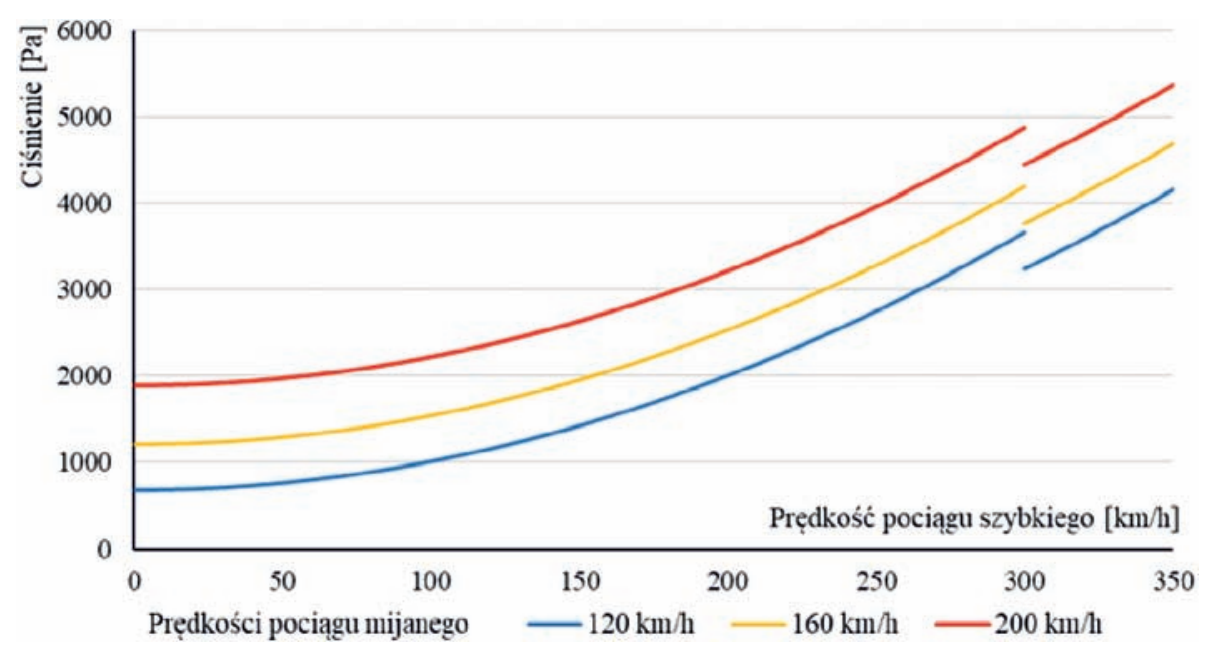

Rys. 5. Ciśnienia na szybie czołowej pociągu mijanego [opracowanie własne]

Tablica 4

Procentowy wzrost ciśnienia na szybie czołowej pociągu szybkiego $\mathrm{w}$ stosunku do $V_{1}=350 \mathrm{~km} / \mathrm{h}$ i $V_{2}=0 \mathrm{~km} / \mathrm{h}$

\begin{tabular}{|c|c|c|c|c|c|c|}
\hline \multirow{3}{*}{$\begin{array}{c}\text { Prędkość } V_{1} \text { (pociągu } \\
\text { szybkiego) }[\mathrm{km} / \mathrm{h}]\end{array}$} & \multicolumn{6}{|c|}{ Wzrost ciśnienia [\%] } \\
\hline & \multicolumn{6}{|c|}{ Prędkość $V_{2}$ (pociągu mijanego) } \\
\hline & $0 \mathrm{~km} / \mathrm{h}$ & $120 \mathrm{~km} / \mathrm{h}$ & $140 \mathrm{~km} / \mathrm{h}$ & $160 \mathrm{~km} / \mathrm{h}$ & $180 \mathrm{~km} / \mathrm{h}$ & $200 \mathrm{~km} / \mathrm{h}$ \\
\hline $\mathbf{0}$ & 0 & 8 & 11 & 15 & 19 & 23 \\
\hline 160 & 21 & 29 & 32 & 36 & 39 & 44 \\
\hline 180 & 26 & 35 & 38 & 41 & 45 & 49 \\
\hline 200 & 33 & 41 & 44 & 47 & 51 & 56 \\
\hline 220 & 40 & 48 & 51 & 54 & 58 & 62 \\
\hline 240 & 47 & 55 & 58 & 62 & 66 & 70 \\
\hline 250 & 51 & 59 & 62 & 66 & 70 & 74 \\
\hline 260 & 55 & 63 & 66 & 70 & 74 & 78 \\
\hline 280 & 64 & 72 & 75 & 79 & 83 & 87 \\
\hline 300 & 73 & 82 & 85 & 88 & 92 & 96 \\
\hline 320 & 84 & 91 & 93 & 96 & 99 & 103 \\
\hline 340 & 94 & 101 & 104 & 107 & 110 & 114 \\
\hline 350 & 100 & 107 & 110 & 113 & 116 & 120 \\
\hline
\end{tabular}

[Opracowanie własne].

Tablica 5

Procentowy wzrost ciśnienia na szybie czołowej pociągu mijanego odniesiony do ciśnienia przy jego prędkości maksymalnej $\left(V_{2 \text { max }}\right)$

\begin{tabular}{|c|c|c|c|c|c|}
\hline \multirow{3}{*}{$\begin{array}{c}\text { Prędkość } V_{1} \text { (pociągu } \\
\text { szybkiego) }[\mathrm{km} / \mathrm{h}]\end{array}$} & \multicolumn{5}{|c|}{ Wzrost ciśnienia [\%] } \\
\hline & \multicolumn{5}{|c|}{ Maksymalna prędkość $V_{2 \max }$ (pociągu mijanego) } \\
\hline & $120 \mathrm{~km} / \mathrm{h}$ & $140 \mathrm{~km} / \mathrm{h}$ & $160 \mathrm{~km} / \mathrm{h}$ & $180 \mathrm{~km} / \mathrm{h}$ & $200 \mathrm{~km} / \mathrm{h}$ \\
\hline $\mathbf{0}$ & 100 & 100 & 100 & 100 & 100 \\
\hline 160 & 224 & 191 & 170 & 155 & 145 \\
\hline 180 & 258 & 216 & 189 & 170 & 157 \\
\hline 200 & 294 & 243 & 209 & 186 & 170 \\
\hline 220 & 335 & 273 & 232 & 205 & 185 \\
\hline 240 & 380 & 306 & 258 & 224 & 201 \\
\hline 250 & 404 & 323 & 271 & 235 & 209 \\
\hline 260 & 429 & 341 & 285 & 246 & 218 \\
\hline 280 & 481 & 380 & 314 & 269 & 237 \\
\hline 300 & 538 & 421 & 346 & 294 & 258 \\
\hline 320 & 527 & 413 & 340 & 290 & 254 \\
\hline 340 & 582 & 454 & 371 & 314 & 273 \\
\hline 350 & 610 & 475 & 387 & 327 & 284 \\
\hline
\end{tabular}

[Opracowanie własne]. 
- przy spotkaniu się z pociągiem jadącym z prędkością $350 \mathrm{~km} / \mathrm{h}$, wzrost ciśnienia na jego szybie czołowej zmienia się znacząco:

- od prawie 3 razy $(2,84)$ dla maksymalnej prędkości $200 \mathrm{~km} / \mathrm{h}$ pociągu mijanego,

- przez blisko 4 razy $(3,87)$ dla maksymalnej prędkości $160 \mathrm{~km} / \mathrm{h}$ pociągu mijanego,

- do nawet ponad 6 razy $(6,1)$ dla maksymalnej prędkości $120 \mathrm{~km} / \mathrm{h}$ pociągu mijanego.

Dane te pokazują, że eksploatacja bardzo różniącego się taboru na tych samych liniach może wiązać się z niebezpieczeństwem uszkadzania szyb czołowych taboru o mniejszych prędkościach maksymalnych, szczególnie starszego już taboru o prędkościach maksymalnych $120 \mathrm{~km} / \mathrm{h}$. Jest to tym bardziej niebezpieczne, że $\mathrm{w}$ czasach kiedy projektowano tabor na prędkości maksymalne $120 \mathrm{~km} / \mathrm{h}$ i $160 \mathrm{~km} / \mathrm{h}$ ówcześni konstruktorzy i producenci nie mogli przewidzieć, że w przyszłości tabor ten będzie kursował po tych samych liniach razem $\mathrm{z}$ taborem o prędkościach maksymalnych $350 \mathrm{~km} / \mathrm{h}$.

Ciśnienia na szybach czołowych przekraczają też znacznie ciśnienie, na które sprawdza się szyby boczne $(2500 \mathrm{~Pa})$. Do niedawna, jedynym badaniem przeprowadzanym podczas testowania wytrzymałości szyb czołowych pojazdów trakcyjnych było strzelanie do tej szyby specjalnym pociskiem. Próba ta jest na tyle krytyczna, że nie były wymagane dodatkowe badania odporności szyby czołowej na działanie ciśnienia. Badanie to wykonywano wcześniej według karty UIC 651 [5], a od 2007 roku również według normy PN-EN 15152 [8] obecne wydanie normy jest z 2019 roku. Metoda wykonania badania według karty UIC różni się nieco od metody zawartej w normie, gdyż wymagane jest ponadto sprawdzenie odporności szyby na zderzenie z drobnymi kamykami (żwir). Jednakże podstawowy parametr - prędkość pocisku uderzającego w szybę była i nadal jest wyliczana z następującej zależności:

$$
V_{\mathrm{p}}=V_{e}+160 \mathrm{~km} / \mathrm{h},
$$

gdzie:

$$
\begin{aligned}
& V_{p} \text { - prędkość pocisku } \\
& V_{e} \text { - maksymalna prędkość eksploatacyjna bada- } \\
& \text { nego pojazdu. }
\end{aligned}
$$

Wyznaczenie prędkości pocisku wynikało z maksymalnej prędkości pociągów $160 \mathrm{~km} / \mathrm{h}$. Zakładano bowiem, że z pociągu jadącego z taką właśnie prędkością może być wyrzucony jakiś twardy przedmiot i uderzyć w szybę czołową pociągu nadjeżdżającego z przeciwka. Do tej pory badanie to okazywało się wystarczające, tzn. szyby, które takie badanie przeszły z wynikiem pozytywnym, nie wykazywały pęknięć pod wpływem gwałtownych zmian ciśnienia przy mijaniu się pociągów, pomimo zupełnie innych kryteriów (wynikających $\mathrm{z}$ innych założeń) oceny szyby po trafieniu pociskiem. Brak zwiększenia prędkości pocisku, pomimo coraz powszechniejszego pojawiania się w eksploatacji pociągów o prędkościach znacznie przekraczających $160 \mathrm{~km} / \mathrm{h}$, wynika najprawdopodobniej $\mathrm{z}$ budowy okien bocznych pociągów. Do prędkości $160 \mathrm{~km} / \mathrm{h}$ wagony pasażerskie i zespoły trakcyjne były wyposażone w okna otwieralne, przez które możliwe było wyrzucenie drobnych przedmiotów. Natomiast od tej samej prędkości $160 \mathrm{~km} / \mathrm{h}$ pojazdy zaczęto wyposażać $\mathrm{w}$ nieotwieralne okna, co nieodłącznie wiązało się $\mathrm{z}$ wyposażeniem tych pojazdów w klimatyzację.

Ze względu na znacznie zwiększoną prędkość mijania się pociągów (prędkość pociągu jadącego z przeciwka może wynosić nawet $350 \mathrm{~km} / \mathrm{h}$, zamiast dotychczasowych $160 \mathrm{~km} / \mathrm{h}$ ) trudno jest przewidzieć, czy dotychczasowe szyby czołowe starszego taboru o prędkości maksymalnej $120 \mathrm{~km} / \mathrm{h}$ będą miały odpowiednią wytrzymałość na zmiany ciśnienia. Należy zatem zapewnić, aby pojazdy trakcyjne (w tym maszyny robocze, drezyny i inne), narażone na mijanie się na sąsiednich torach $\mathrm{z}$ pociągami szybkimi, były wyposażone w okna o odpowiedniej wytrzymałości lub wprowadzić rozwiązania uniemożliwiające „spotkanie się" pojazdów o tak znacznych różnicach prędkości dopuszczalnych.

\section{Wnioski}

Jak wskazują autorzy różnych publikacji, to pociąg poruszający się z dużymi prędkościami oddziałuje na pociąg poruszający się wolniej i na inne obiekty, a nie odwrotnie. Przyjmując założenie, że pociągi dużych prędkości zostały odpowiednio zaprojektowane - tak, aby ich konstrukcja wytrzymała ciśnienia i wywołane nimi siły oddziaływania powstające podczas jazdy z prędkościami maksymalnymi, należy przeanalizować, czy pozostałe pociągi starszej konstrukcji mogące mijać się z pociągami dużych prędkości nie będą narażone na zbyt duże ciśnienia i wywołane tym siły. Jak wynika z przeprowadzonych rozważań, boczne okna wagonów pasażerskich, zespołów trakcyjnych i lokomotyw, których okna przebadano na zgodność z kartą UIC 566, mogą bez żadnych ograniczeń kursować na tych samych trasach, co pociągi szybkie. Nie ma konieczności wymiany okien bocznych, ani podejmowania innych środków zaradczych. Jedynym niebezpieczeństwem może być „wyssanie” całej szyby w przypadku zbyt słabego jej zamocowania w poszyciu pojazdu.

Przyjęto analogiczne założenie, że szyby czołowe lokomotyw i zespołów trakcyjnych w pociągach dużych prędkości zostały odpowiednio zaprojektowane 
tak, aby ich konstrukcja wytrzymała ciśnienia i wywołane nimi siły oddziaływania powstające podczas jazdy z prędkościami maksymalnymi. Analiza wykazała, że wzrost ciśnienia na szybie czołowej pociągu szybkiego o prędkości maksymalnej $350 \mathrm{~km} / \mathrm{h}$ mijającego się z pociągiem wolniejszym, jadącym nawet $200 \mathrm{~km} / \mathrm{h}$, wynosi maksymalnie 1,2 razy.

Natomiast $\mathrm{w}$ pociągach o mniejszych prędkościach maksymalnych mijających się z pociągiem jadącym $350 \mathrm{~km} / \mathrm{h}$ następuje znaczący wzrost ciśnienia na szybie czołowej od prawie 3 razy - dla pociągu o prędkości maksymalnej $200 \mathrm{~km} / \mathrm{h}$, poprzez blisko 4 razy - dla pociągu o prędkości maksymalnej $160 \mathrm{~km} / \mathrm{h}$, do nawet ponad $6 \mathrm{razy}$ - dla pociągu o prędkości maksymalnej $120 \mathrm{~km} / \mathrm{h}$. Zatem eksploatacja różnego taboru na tych samych liniach może wiązać się z niebezpieczeństwem uszkadzania szyb czołowych szczególnie starszego już taboru o prędkościach maksymalnych $120 \mathrm{~km} / \mathrm{h}$. Należy eksperymentalnie potwierdzić, czy pojazdy trakcyjne starszego typu, narażone na mijanie się na sąsiednich torach $\mathrm{z}$ pociągami szybkimi, są wyposażone $\mathrm{w}$ okna o odpowiedniej wytrzymałości. W razie potrzeby należy wprowadzić rozwiązania uniemożliwiające „spotkanie się" pojazdów o tak znacznych różnicach prędkości dopuszczalnych.

\section{Literatura}

1. Assessment of potential aerodynamic effects on personnel and equipment in proximity to high speed train operations: Safety of High-Speed Ground Transportation Systems Final Report, U.S. Department of Transportation Federal Railroad Administration, December, 1999.
2. Colin P.E.: Impulsive Pressures in the Train Passing Problem, Proceedings of the First Symposium on Road Vehicle Aerodynamics at the City University, London, 1969, Paper 11.

3. Gawthorpe R.G.: Aerodynamics of Trains in the Open Air, Railway Engineering International, Volume 3, Number 3, May/June, 1978.

4. Karta UIC 566: Wytrzymałość pudeł wagonów osobowych i ich elementów", wydanie 3, 01.01.1990

5. Karta UIC 651: Ukształtowanie kabin maszynisty lokomotyw, wagonów silnikowych, zespołów trakcyjnych i wagonów sterowniczych", wydanie 4, lipiec 2002.

6. Kubski K.: Badania rozkładu prędkości strumienia powietrza $w$ podmuchach wywołanych jazda pociagu i wzajemnego wpływu mijajacych sie pociagów na zmiany ciśnienia statycznego działającego na ściany wagonów i na powierzchnię czołowa lokomotywy, praca badawcza Centralny Ośrodek Badań i Rozwoju Techniki Kolejnictwa (COBiRTK), Warszawa, styczeń 1974.

7. PN-EN 14067-4+A1:2019-03: Kolejnictwo Aerodynamika - Część 4: Wymagania i procedury badań aerodynamicznych na szlaku.

8. PN-EN 15152:2019-12: Kolejnictwo - Szyby przednie pojazdów trakcyjnych.

9. PN-EN 15273-2+A1:2017-03: Kolejnictwo Skrajnie - Część 2: Skrajnia pojazdów szynowych.

10. Rozporządzenie Komisji (UE) nr 1299/2014 z dnia 18 listopada 2014 r. dotyczące technicznych specyfikacji interoperacyjności podsystemu „Infrastruktura” systemu kolei w Unii Europejskiej.

11. Sockel H.: The Train Passing Problem, von Karmen Institute for Fluid Dynamics, Lecture Series 48, High Speed Ground Vehicles, April 10-14, 1972, Rhode-Saint-Genese, Belgium, 1972. 